\title{
An empirical assessment of how the government policies influenced the performance of the SMEs in Zimbabwe
}

Godfrey Tambudzayi Musabayana ( $\square$ musabayanagt@gmail.com )

University of KwaZulu-Natal School of Social Sciences https://orcid.org/0000-0002-9827-5533

\section{Emmanuel Mutambara}

University of Kwazulu-Natal College of Law and Management Studies

Tony Ngwenya

University of Kwazulu-Natal College of Law and Management Studies

\section{Research}

Keywords: Government policy, SME performance, SME implementers

Posted Date: May 10th, 2021

DOI: https://doi.org/10.21203/rs.3.rs-500309/v1

License: @) (1) This work is licensed under a Creative Commons Attribution 4.0 International License. Read Full License 


\section{Abstract}

The Zimbabwean government came up with sound policies that were enacted in order to deliberately empower the SMEs, focusing on their performance, but the main challenge was on the communication, implementation and support of the policies hence their impact was highly insignificant. Primary data showed that the government managed to inform the elite group, its officers who are well versed with SME policies and government intentions were clearly communicated to all the experts in the SME sector, but this information did not reach out to the end users, SME implementers. The failure to inform the lower levels of the SME implementers with the policy information had a negative impact on the performance of SMEs and the government should take this as a learning curve and adopt new strategic framework that is poised to put right what has been incorrectly executed. The poor performance of Zimbabwean SMEs is basically an issue of the government commitment to its policies that support the economic growth. The SME policy issues that were not communicated to the implementers had a ripple negative effect across the whole economy of the country hence the study recommended the crafting of a more robust and home grown strategic framework that corrects the mistake that was made the government.

\section{Introduction}

\subsection{The influence of government policy on SME performance}

The development of a sound government policy for SMEs growth is an indispensable component of the strategy of most economies and holds significance to the growth, development and performance of SMEs (Ifekwem, 2019). SMEs which lacked government support policies have restricted access to improving their growth and performance. Government policy is reflected in strategic plans and policy memo and it is translated and carried out through rules and regulations, manuals, requests for proposals, contractual agreements and enforcement actions (Ifekwem, 2019). The advancement of SMEs in the developed nations has been achieved by the policies that supported the performance of SMEs. It is in this vein that the government policy framework has a great bearing on the performance of the SMEs.

Government institutions can clearly influence the rate of entrepreneurship. Public policies can basically determine the entrepreneurial dynamics of a country or region by introducing specific policies that promote entrepreneurship as well as by creating a general institutional structure conducive to entrepreneurship (Sobel et al. 2007). Wakili, (2016) reiterated that government support policies on SMEs are strategies or programmes employed by government and their regulatory agencies to influence and determine decisions making process that foster economic growth by ensuring that the environment is adequately protected for business operations. The government should have well established structures to ensure that its policies are implemented and monitored using the tools it will have developed.

Zimbabwe crafted indigenous policies to redress the dominance of the multinational companies and focused on the SMEs which was embraced by the local communities. It brought up some positive results which include an increase in the number of SMEs establishment and the involvement of the black people in entrepreneurship programmes. The SMEs took the centre stage and their value was stated by Wang, et. al (2011) who pointed out that in developing countries such as in Zimbabwe, SMEs are important for driving the growth and economic development. This view was shared by Zvarivadza (2018) who states that most SMEs are born out of the people or groups of people with the visions to operate and run prosperous businesses. However, the new policy framework did not do much to improve the economy of Zimbabwe. This was alluded by Block (2013) who states that empowerment policy has negatively affected the ability of Zimbabwean economy to attract foreign direct investment. These sentiments show that effects of the indigenous policies on the economy of Zimbabwe which has greatly deteriorated. It is against the backdrop of this policy implementation gap that this study is anchored on the empirical findings to establish the policy gaps and recommend the strategies which Zimbabwe can employ to improve the performance of SMEs and bring Zimbabwe back on the economic map and compete with the likes of South Africa, Batswana and Zambia who are performing well in SADC region.

\section{Methodology}


The Sequential Exploratory Strategy was used by in the study and it employed both the qualitative and quantitative data collection methods. Addae and Quan-Baffour (2015) argue that by dominance the researcher asks the question of which of the two approaches should take supremacy in the study and which approach should be widely used in the study and decide on which of the approaches would be used in the initial stages and which one would be used in latter stages of the study. This approach provided the study with a comparative advantage gained from the two data collection methods in that the short comings of one method were covered up by the other one. The data was collected in two phases.

The first phase of the qualitative research involved in depth interviews in order to develop a practical understanding of the strategic policies and how they impact on SME performance. In in depth interviews the researcher looked for rich in depth answers which tap deeply into the respondents own experiences, feelings and opinions (Lee, 2008). The information from the interviews was analysed and developed some themes that were used in the second phase. The second phase used the results obtained in phase one and developed a survey to test the generalisability of the findings. The researcher selected the key results findings from the first phase and used them to develop the questionnaires which were used to solicit information from SME implementers which was quantitative in nature.

\section{Literature Review}

\subsection{The African policies and performance of SMEs}

The importance of SMEs in the African states cannot be over emphasized. In Africa, SMEs accounts for more than $90 \%$ of businesses and contribute about 50\% and Gross National Product (GDP) (Fjose et al., 2010; Kamunge et al., 2014). In Kenya, SMEs contribute $40 \%$ of the GDP, over $50 \%$ of new jobs and account for $80 \%$ of the workforce (Mwarari \& Ngugi, 2013). In 2003, SMEs offered employment to 3.2 million Kenyans (Kauffman, 2006). Similarly, SMEs accounted for $70 \%$ of Nigerian industrial jobs and $95 \%$ of the manufacturing sector (Kauffman, 2006) while in Ghana SMEs accounts for $70 \%$ of all businesses and employed $70 \%$ of the total workforce (World Bank, 2016). The sector also amounts to $97 \%$ of businesses and $18 \%$ of workforce in Zambia (Parker, 2006).

African countries have crafted policies that support the advancement of SMEs. In developing countries, the concern for the role of SMEs in the development process continues to be at the forefront of policy debates as they comprise a majority of the business population in most countries, and therefore play a crucial role in the economy (Mitchell and Reid, 2000).

Hansen et al. (2015) attributes that local content policies and programmes in Tanzania, the Mining Act of 2010 stipulates that certain parts of the exploration cycle are reserved for companies that are solely owned by Tanzanian citizens and there are provisions to promote backward and forward linkages.

The development of SMEs is an essential element in the growth strategy of most economies and holds significance for Nigeria (Udechukwu, 2003). Government support policy act as a moderator to strengthen the relationship between entrepreneurial orientation and contemporary marketing on the performance of SMEs in Nigeria (Ibrahim and Mustapha, 2019). The SME policy of Nigeria has more emphasis on the performance of the entrepreneurs, marketing of the products and protecting the SMEs from external competition that would reduce the demand of the local products. In this regard, Federal government of Nigeria announced the reduction of taxes for SMEs to thrive and promote inclusive economic growth and the Nigerian government through the Nigerian Customs Services banned the importation of goods that can be sourced and produced in Nigeria (Wakili, 2016). This policy aims at encouraging the indigenous SMEs to strengthen their market potentials which will subsequently improve their productivity and performance (Omonobi \& Bivbere, 2016). These sentiments were echoed by Osinbajo, (2015) WHO stated that the government of Nigeria resolves to engage more with SMEs and entrepreneurial activities towards ensuring viable economic development and wealth creation by supporting the sector. The Nigerian government showed its support of SMEs through crafting the policies that provided a fertile environment for the performance of SMEs. 
The government of Ghana has provided a fertile ground for the development of the SMEs. The SMEs' significance to the Ghanaian economy is clear as the government support exhibited the greatest influence on behaviour intention and showed substantial influence on performance of SMEs (Awiagah, Kang, \& Lim, 2015) The Ghanaian government policies and initiatives played a remedial role through subsidies and tax incentives to facilitate SME exposure to information technology and stimulate the adoption and use of ecommerce.

The SME development in Ghana according to Abor and Biekpe (2006) is based on the idea of SME promotion that dates back to 1970 though very little was done at the time, in recent years the government key institutions were set up to assist SMEs and prominent among them are the Office of Business Promotion and the present Ghana Enterprise Development Commission (GEDC). The main objective of GEDC was to assist Ghanaian businessmen to enter into fields where foreigners mainly operated, it had packages for strengthening small scale industry in general, both technically and financially (Kayanula and Quartey, 2000). The government of Ghana provided the supporting environment for the success of SMEs, hence their huge contribution to the economy of the country.

Small scale enterprises play an important role in the Kenyan economy and are accorded high priority in the development policy (GOK, 2007). The economy of Kenya grew by an average of $4.3 \%$ in the recent past (year 2009), the SMEs contribute significantly to this growth, and offers employment to many people both in the rural and urban areas (Osoro and Muturi, 2013). SMEs dominate the manufacturing sector in Kenya., about $85 \%$ of manufacturing firms in Kenya are small, contributing only about $20 \%$ of sector's GDP. (Kippra, 2017). These sentiments were supported by Osoro and Muturi (2013) who stated that the SME contribute immensely to the economic development and wealth creation through employment creation estimated at 3.2 million people in 2003 , generation of incomes, increasing productivity, facilitating technological transfers and creation of market linkages among other benefits.

\subsection{The influence of policies on the performance of SMEs in the SADC Region}

The government of Botswana has designed several policies to support the performance of SMEs. The policy of financing SMEs began in 1982 with the establishment of the Financial Assistance Policy (FAP) (AFDB/OECD, 2005). The main objective of this policy was to stimulate investment in sustainable economic activities, to further support enterprise development (Khanie, 2018). The FAP scheme experienced some implementation problems and it was replaced by the Citizen Entrepreneurial Development Agency (CEDA) in 2001 after the introduction of the Small Medium Micro Enterprise (SMME) Policy and the goal of CEDA is to provide loans to businesses at subsidized interest rates (Local Enterprise Authority, 2009). The government of Botswana showed a continued support of SMEs through its policies that promoted the development of SMEs and the participation of the youth and the empowerment of women through SME programmes.

The Botswana government encouraged research and development on its policies in order to improve its delivery to the nation. The Botswana Institute for Development Policy Analysis (BIDPA) is an independent trust, which started operations in 1995 as a non-governmental policy research institution with a mission is to inform policy and build capacity through research and consultancy services (Khanie, 2018). BIDPA is part-funded by the Government of Botswana as it supports the government to be more objective in its policy creation, implementation and evaluation.

The government of Malawi has placed major emphasis on the development of policies that support SMEs in the country. These sentiments were echoed by Ndola and Moto (2019) who state that the government of Malawi recognizes the contribution made by micro, small and medium enterprises in stimulating competition, providing employment and distributing wealth. There have been attempts by the Malawian government to develop the entrepreneurial mind-set of the population through the revamping and restructuring of public organisations entrusted with national entrepreneurship development such as Technical Education, Vocational and Entrepreneurial Training Authority (TEVETA), Small and Medium Enterprise Development Institute (SMEDI) and Malawi Rural Development and Enterprise Fund (MARDEF) (Ndala \& Pelser, 2019). 
Malawi embarked on a programme of promoting Higher Education Institutions (HEls) both public and private that are offering entrepreneurship education and training which are registered by the National Council for Higher Education (NCHE) with the sole purpose of spurring entrepreneurship development in the country through the provision of Entrepreneurship Education and Training (EET) Delaney, Harrington \& Toker (2019). The programme was targeting the improvement of SME performance through entrepreneurial education.

Malawi Government has supported exchange programmes with China in order to develop the SME sector. On this effect, the Minister of Industry, Trade and Tourism Henry Mussa as reported in the Africa Report (2018) stated:

One of these paths is the establishment of technical colleges. But bearing in mind that the labor market is limited, we encourage people to open [their own] businesses and the trip to China was to expose some of the SMEs to what and how advanced countries manage [these businesses], The government established colleges where the youth and SME owners will be trained in various business and vocational skills, and this will ultimately put money into their pockets and also improve the country's economy

The government policies have provided the environment for the development of the SMEs in Malawi. Its support to the SME sector indicates a positive development of the economy as this will result in more locals taking up entrepreneurship as a profession and a source of employment.

The Broad Black Economic Empowerment (B-BBEE) is the fundamental policy for the development of SMEs in South Africa. In terms of B-BEE, one of its primary objectives is to improve SMEs' access to finance (DTI, 2007). These sentiments were supported by Juggernath (2013), who stated that B-BBEE creates provisions for SMEs to access finance. In view of these two citations it implies that the government had a great vision of empowering the local people through the financial resources which are a major component for the running a business. SMEs were viewed by the government as a source of employment as stated by Rust (2006) that to combat increasing unemployment the creation and support of SMEs is needed and it is very evident that for B-BBEE to succeed in South Africa a full support of small businesses has to be implemented.

Another aspect of resources that the B-BEE policy focused on was human resource and skills development for the SME owners and operators. This meant that the research and development was considered as a main policy item for the development of SMEs. The government would provide a variety of courses to equip the SME operators including the technical training, financial management training, strategic planning and marketing. The trainings would empower the indigenous people and would professionally run their organisations. The South African government has given the SMEs a major priority as a tool of black empowerment hence the development of SMEs is the driving force behind black empowerment.

\subsection{The influence of the Zimbabwean policies on the performance of SMEs}

The new economic dispensation in Zimbabwe, following the land redistribution programme which led to the death of the formal industry led to establishment of the black empowerment policies. The policies of Zimbabwe were inclined towards the SME sector. The collapse of the formal industry and the demand of intermediate technologies by small-scale farmers have provided opportunities for informal business enterprises to produce and supply intermediate agricultural technologies to the new crop of farmers that emerged following the agrarian reform of 2000 widely known as the Fast Track Land Reform Programme (FTLRP) (Makate et al., 2016; Mujeyi, Mutambara, Siziba, Sadomba, \& Manyati, 2015). The policies targeted the SMEs as the provider of the economic recovery path.

Magaisa and Matipira (2017) emphasises that the National Policy and Strategy for SMEs outlines the framework and sets out strategies for the implementation, coordination and monitoring of the SMEs to enhance the growth and development of the sector. The main objective of the creation of the policy framework is towards the creation of sustainable jobs, reduce poverty, stimulate growth and generate foreign currency earnings and there is an objective of creating an enabling environment so as to double the number of small businesses in Zimbabwe. The SMEs took the centre stage and their value was stated by Zvarivadza (2018) who pointed out that most SMEs are born out of the people or groups of people with the visions to operate 
and run prosperous businesses. The main purpose of the policy is to promote the performance of the SMEs through the provision of an enabling environment. The implementation of the Zimbabwe's indigenous policies saw the new era of SMEs being ushered in as the main economic drivers of the new economic dispensation in the absence of the multinational companies.

\subsection{The learning and experience curve effects for Zimbabwe SME from African counterparts}

It is generally agreed by scholars that SMEs contribute significantly to economic development of all nations and they are associated with discovering of new markets and exploiting them to their advantage (Muriithi, 2017). In the same vein, they are considered to be the heart of founding new ventures and a source income and employment for millions of Africans which means that SMEs are central to wealth creation by stimulating demand for goods, investment and trade (GEM, 2006). Without SMEs, many African governments will experience financial and developmental constraints, all which would only worsen living standards of low income persons often served by the sector (Santrelli \& Vivarelli, 2007). Zimbabwe can draw lessons from the literature that SMEs are a force to reckon with in the economic development of the country.

The role of the government in facilitating and supporting SMEs remain critical worldwide as it creates the right or undesirable environment for businesses growth, when the government pays little attention to SMEs sector, then, the sectors is prone to suffer leading to many businesses being unable to survive. A government that does not support SMEs does not only hurt the sector but experiences negative growth in its economic development. The environment created by the government in terms of wages framework, taxation, licencing, opportunities, technological support and infrastructure pave the road to success or failure for the SMEs (Muriithi, 2017). These sentiments were echoed by Kamunge et al, (2014) who summed up the role of the government by stating that depending on the regulatory frameworks put in place by the government, can easily crush or promote small business economy.

It is notable that unfavourable tax system, unfair competition, complicated rules and regulations and punitive environment cripplingly and negatively obstruct SMEs growth (Krasniqi, 2007). These legal requirements vary from one country to another and affect the performance of SMEs. It takes 100 days to establish a business in Kenya, 220 days in Ghana and 350 days in Nigeria to obtain all business licenses (Benzing \& Chu, 2012). Murithi, (2017) states that the tax paid by the businesses also differs with Kenya requiring $51 \%$ of total profit while Ghana demands $33 \%$ and Nigeria $30 \%$ respectively. Besides taxes, it has been found that SMEs in Africa face lengthy and costly delays during numerous procedures and clearances demand by various regulatory frameworks. The stringent measures that are put in place by the governments discourages development and negatively affects the SME implementers and Zimbabwean government need to take cognisance of such disastrous pitfalls.

The differences in the registration process definitely mean that motivation to SMEs operations and continued growth differs across the continent and countries like Kenya and Nigeria are said to have put measures meant to support SMEs especially in the informal sector and they have also reduced government interference to business operations (Benzing \& Chu, 2012). Kenya, specifically is singled out as having put different mechanisms meant to increase access to the youth, women groups and SMEs by setting special funds accessible through public initiatives and financial institutions (Muriithi, 2017). Zimbabwe can draw lessons from these developments in other African states. Positive lessons from Kenya can be duplicated in Zimbabwe especially supporting the vulnerable groups of the society like the youths and women. The positive results on the performance of SMEs is an indicator of the government's power to improve the performance of SMEs.

Zimbabwe has to be aware of the reality that SMES in Africa are operating under difficult and unsuitable conditions. SMEs operating in Africa face many challenges that deter their growth (Nikolić, Dhamo, Schulte, Mihajlović \& Kume, 2015). This is supported by Kamunge et al. (2014) who observed that beside their positive role to development, SMEs face many obstacles that restrict their long term survival. The rate of business failure in Africa is alarming with only a few businesses surviving a few months to one year (Kenya National Bureau of Statistics, 2007). Adcorp (2014), state that the mortality rate of SMEs among African countries remains very high with five out of seven new businesses failing in their first year. Chad has also been 
named as a country with failure of $65 \%$ and one of the most difficult countries to do business due to unfavourable regulatory frameworks (World Bank, 2012). In Uganda, for example one third on new business start-ups do not go beyond one year of operation while in South Africa, the failure is between $50 \%$ and $95 \%$ depending on the industry (Willemse, 2010). A study by Muriithi (2017). also revealed that $75 \%$ of SMEs in South Africa do not become established businesses making the country to have the highest failure rate in the world. Despite these disturbing statistics, SMEs dominate the South African economy, their contributions cannot be ignored (Sawers et al., 2008). This scenario brings in another learning moment for the Zimbabwean government that the success of SMEs requires a lot of support, patients, research and development and implementation of the innovation processes including the value creation and addition of the goods and services produced.

\section{Results- Presentation And Analysis Of Data 4.1 Understanding of the two policies}

The qualitative data was collected from ten respondents who were purposefully selected from a group of experts in SME policy formulation, implementation and the cognate monitoring and evaluation of SME programme. The participating respondents could be described as the employees of the government departments, non-governmental organisations and leaders of SME organisations. The respondents were knowledgeable of government processes of policy formulation, information dissemination and the general implementation processes. Table 1 shows the results of the ten respondents that participated during the uncontrived interview process in evaluating the understanding of the indigenisation and empowerment policy:

Table 1

Understanding of the indigenisation and empowerment policy

$n=10$

Understanding of indigenisation and empowerment policy

\begin{tabular}{|c|c|c|}
\hline $\begin{array}{l}\text { Aspects that emerged to express understanding of } \\
\text { indigenous empowerment policy }\end{array}$ & $\begin{array}{l}\text { Key informants who mentioned the same } \\
\text { (e.g. K01, K07, K8, etc.) }\end{array}$ & $\begin{array}{l}\text { Total number of } \\
\text { key informants }\end{array}$ \\
\hline It promotes equal opportunities for all citizens & $\mathrm{KO} 2, \mathrm{KO3}, \mathrm{KO4}, \mathrm{KO7}, \mathrm{K} 05$ & 5 \\
\hline $\begin{array}{l}\text { A policy which unlocks wealth creation by the } \\
\text { indigenous population in the country }\end{array}$ & K08, K02, K04, K09, K10, & 5 \\
\hline $\begin{array}{l}\text { Training of the Zimbabwean citizens on business } \\
\text { ethics. }\end{array}$ & K09, K08, K03, K05, & 4 \\
\hline $\begin{array}{l}\text { A policy which facilitates funding for investment in } \\
\text { the country }\end{array}$ & K09, K02, K04 & 3 \\
\hline $\begin{array}{l}\text { It promotes the local Zimbabweans to be responsible } \\
\text { citizens }\end{array}$ & K01, K02 & 2 \\
\hline
\end{tabular}

The respondents indicated that they were aware of the indigenisation policy and showed a great understanding of tenants of the policy. The female respondent KO1 who works for the government elaborated the indigenisation policy when she stated:

"It is the policy that was put in place by the government to help the Zimbabweans to improve national development. It helped them to do their business and it was good for change in the structure of who creates wealth and employment in the country. Remember big companies had closed down. The indigenisation policy is a policy that promotes the local Zimbabweans to be in charge of the country.

Another male respondent K07, who is in the manufacturing sector expressed his knowledge of the indigenisation policy as follows: 
The indigenisation and empowerment policy promotes equality among the people of Zimbabwe in terms of opportunities and development of the country. This policy deal with the equal access to the wealth of the country. Zimbabwe is rich in natural resources like farming, mining, wild life and vegetation which must benefit every Zimbabwean.

The respondents were asked to describe their own understanding of the Industrial policy and the results are in the Table 2

Table 2

Understanding of the Industrial Policy

\section{Understanding of industrial policy}

\begin{tabular}{|c|c|}
\hline Aspects that emerged to express understanding of industrial policy & $\begin{array}{l}\text { Key informants who mentioned } \\
\text { the same (e.g. K01, K07, K8, } \\
\text { etc.) }\end{array}$ \\
\hline
\end{tabular}

It is a policy that is designed to improve the economy of the country through sustainable support to SME`s and value chain management

$\mathrm{K} 01, \mathrm{~K} 02, \mathrm{~K} 03, \mathrm{~K} 05, \mathrm{~K} 07, \mathrm{~K} 09 \quad 6$

It is a policy that was intended to improve the country`s technology

$\mathrm{K} 01, \mathrm{~K} 02, \mathrm{~K} 03, \mathrm{~K} 04, \mathrm{~K} 07$

5

It enables the intervention of the Government on capacity building of business operators in the country

It promotes local industries and entrepreneurship

$\mathrm{K} 08, \mathrm{~K} 04, \mathrm{~K} 07, \mathrm{~K} 08$

4

It has a mechanism to ensure that cohesion exists between the producers and the retailers.

$\begin{array}{ll}\mathrm{K} 01, \mathrm{~K} 03, \mathrm{~K} 05, \mathrm{~K} 06 & 4 \\ \mathrm{~K} 08, \mathrm{~K} 09, \mathrm{~K} 10 & 3\end{array}$

The respondents showed a high level of understanding of the industrial policy. The female respondent KO6 who is in the construction company had this to say about the industrial policy:

The industrial policy has to do with improvement of the local business. It promotes the local industries which include the farmers, manufacturers, retailers and all the sectors involved with the economic development of the nation. It is important to note that the policy focuses on the total development and improvement of the local industries through all the support services like infrastructure, technology and research and development.

A male respondent $\mathrm{K} 010$ who is in the agriculture sector also indicated a high level of understanding of the industrial policy. In his explanation, he had this to say:

The industrialisation policy focused on building of the economy through SMEs. The government stressed that the SMEs can be harnessed into a productive sector for the development of the country's economy. The industrial policy provides all the support that the government would provide to the SMEs in order to make the sector the backbone of the economy of Zimbabwe.

It can be concluded that the respondents who were interviewed showed a great understanding of the two policies and have high knowledge levels of the policies as indicated by the response that were provided. These results were used to solicit the information from the lower levels and the starting point was to address the following question: Was the policy information disseminated to the SME operators and other stakeholders?

\subsection{Awareness of the two polices among the implementers}

A questionnaire was used to solicit information that addressed the implementers' awareness of government policies and their effects on SME performance. Firstly the policy implementers were asked to rate their performance from 2015 to 2019 and the summary of the results are shown in the graph below.

Figure 1 shows that there is generally low performance of SMEs as most of the respondents selected "Very bad" as the option for the performance of their business during the period under review. This concurs with the study done Majoni et al. (2016: 
382) who confirmed that 'SME failure is high in Zimbabwe because of poor training and monitoring of the sector by Government.' The secondary information correlates with the primary data representing the SME implementers.

The respondents were asked to indicate how much they know about the Indigenisation and Empowerment Policy and the Industrial Policy that promote SMEs in Zimbabwe selecting a response from the four options. "Not at all, Very little, To some extent and To a great extent" The results have been presented using the graph as shown in Fig. 2.

Figure 2: Awareness of the two polices among the implementers

Graphical representation of the results indicating awareness of the Indigenisation and Empowerment Policy and the Industrial Policy.

Considering the 10 items, the awareness of the policies is quantified by items $1-7,10$. Items 8 and 9 are measuring the operation effect of the SMEs within the policy framework. Therefore, a composite measure for awareness of the policies (AWARE) was obtained by adding together responses to the 8 items listed above. These responses were considered as a cumulative score of awareness - total awareness in all areas. This summated measure will range from 8 ( $\mathrm{min}=$ not at all for all 8 items) to 32 (to a great extent for all 8 items). This composite measure provided the data that addressed the respondents' awareness of the policies.

The Analysis (chi-square goodness-of-fit test) was done to test the correlation between AWARE and the 5 measures for performance and it showed that a significant number scored from 8 to $12, p<.0005$. The chi-square goodness-of-fit test was an appropriate test to analyse the data.

Pearson's and Spearman's correlation: Spearman's correlations measure how ordinal variables or rank orders are related. Pearson's correlation coefficient is a measure of linear association.

Table 3

Analysis of the relationship between policy awareness and performance of SMEs

\begin{tabular}{|c|c|c|c|c|c|c|c|}
\hline \multicolumn{8}{|l|}{ Correlations } \\
\hline & & & $\begin{array}{l}\text { Performance } \\
2019\end{array}$ & $\begin{array}{l}\text { Performance } \\
2018\end{array}$ & $\begin{array}{l}\text { Performance } \\
2017\end{array}$ & $\begin{array}{l}\text { Performance } \\
2016\end{array}$ & $\begin{array}{l}\text { Performance } \\
2015\end{array}$ \\
\hline \multirow[t]{3}{*}{$\begin{array}{l}\text { Spearman's } \\
\text { rho }\end{array}$} & AWARE & $\begin{array}{l}\text { Correlation } \\
\text { Coefficient }\end{array}$ & -.016 & .032 & .026 & -.019 & .026 \\
\hline & & $\begin{array}{l}\text { Sig. (2- } \\
\text { tailed) }\end{array}$ & .718 & .482 & .558 & .666 & .560 \\
\hline & & $\mathrm{N}$ & 499 & 499 & 499 & 499 & 499 \\
\hline
\end{tabular}

The analysis of the relationship between policy awareness and performance of SMEs indicate that there is no correlation between awareness of the policies and performance from 2015 to 2019.

\subsection{Effects of government policies on SME performance}

The interviewees were asked to explain the effects of government policies on SME performance. The results are shown in Table 4. 
Effects of government policies on SME performance (Interviewees)

\section{Objective 1: Government policy aspects that have positively influenced the performance of SMEs in Zimbabwe}

\begin{tabular}{|lll|}
\hline $\begin{array}{l}\text { Aspects mentioned that positively influenced } \\
\text { performance of SMEs }\end{array}$ & $\begin{array}{l}\text { Key informants who mentioned the same } \\
(\mathrm{e} . \mathrm{g} . \mathrm{K} 01, \mathrm{~K} 07, \mathrm{~K} 8, \mathrm{etc} .)\end{array}$ & $\begin{array}{l}\text { Total number of key } \\
\text { informants }\end{array}$ \\
\hline $\begin{array}{l}\text { Dissemination of vital information thorough } \\
\text { Public and private media }\end{array}$ & $\begin{array}{l}\mathrm{K} 01, \mathrm{~K} 02, \mathrm{~K} 03, \mathrm{~K} 04, \mathrm{~K} 05, \mathrm{~K} 06, \mathrm{~K} 07, \mathrm{~K} 08, \mathrm{~K} 09, \\
\mathrm{~K} 10\end{array}$ & 10 \\
\hline Provision of affordable loans & $\mathrm{K} 01, \mathrm{~K} 05, \mathrm{~K} 08, \mathrm{~K} 09$ & 4 \\
\hline Provision of Inputs & $\mathrm{K} 10, \mathrm{~K} 04, \mathrm{~K} 08$ & 3 \\
\hline $\begin{array}{l}\text { Establishment, design and implementation of } \\
\text { SMEs trainings }\end{array}$ & $\mathrm{K} 10, \mathrm{~K} 07$ & 2 \\
\hline $\begin{array}{l}\text { Provision of productive land } \\
\text { K01 }\end{array}$ & $\mathrm{K} 01$ & 1 \\
\hline
\end{tabular}

The respondents indicated that the government used public and private media such as the national newspapers, radios and television sets as a means of disseminating information to the SME stakeholders. These sentiments were emphasised by a male responded $\mathrm{KO2}$, who works in the transport sector and had this to say:

The government mostly used public media. The state newspapers, the radio and the televisions were used to disseminate the necessary information for the entrepreneurs. I still remember reading about the policies in the newspaper where the Minister of SMEs was talking about the SMEs and how the government is encouraging people to be involved in this sector. The public media provides the information to the SME operators.

The respondents stated that the government did not provide much support to the SMEs in terms of loans, farming inputs and training. In the instances where the government made an effort to assist the SME operators, there were no formal procedures for the selection of beneficiaries and very few people benefitted from such programmes. The male responded K05 from the manufacturing sector stated the following about the provision of government support to the SME operators:

"The SMEs were empowered by the government through funding. Some SME operators received money from the government for their operations even though a very small number received the money but at least they got something. Some operators were assisted to find market for their products and they got help because they were registered by the government." (

Despite the mention of government assistance by some respondents, the respondent $\mathrm{K} 03$ who is in the mining sector sounded bitter with the government when he emphasized that the government did not do much to assist the mining sector:

As I have said it already. The government is not helping much. People are in need of money to buy the chemicals for blasting, compressors and so many more other mining equipment but that money is not coming at all.

The interviewees indicated that the government's support to the SME implementers was very insignificant and did not make any impact on the performance of the SMEs. The information on the views of the implementers was collected from the questionnaires using the themes developed from the interview results. The implementers were asked to indicate how much how much the government policies have influenced the performance of their organisations. The results were presented in graphs. Figure 3 provides the results of the responses on the effect of government policies on the performance of SMEs in figures and the data will be later presented in graphs.

The results indicate that the response 'Not at all' was selected significantly more than the other responses for all the items. The response "To a great extent" was least selected by the respondents. A significant number of the SME operators who responded to the questionnaires indicated that the government assistance did not help them to improve their performance. The interviewees who stated that very small government support was provided to the SME implementers supported these sentiments 


\section{Interpretation And Discussion Of Data \\ 5.1 Understanding of the two Policies}

Some notable features to the responses given by the interviewees were that they demonstrated that that they have a clear understanding of both the indigenisation and empowerment policy and the industrial policy. Each of the interviewees mentioned a correct attribute of the two policies as stated in the two policy documents which means that they were familiar with the policies. The response to the understanding of the indigenisation and empowerment policy showed that $50 \%$ of the interviewees stated that the policy promotes equal opportunities for all citizens, another $50 \%$ said that the policy unlocks wealth creation by the indigenous population in the country, $40 \%$ said the policy trains the Zimbabwean citizens on business ethics and the other $40 \%$ mentioned that the policy facilitates the funding for investment in the country. The policy issues that were raised by the interviewees are in line with the Indigenisation and Economic Empowerment Act (IEEA) Chap. 14:33, Act $14 / 2007$ which has all the facts that have been mentioned by the respondents. On the understanding of the industrial policy, sixty percent of the interviewees stated that it is a policy that is designed improve the economy of the country through sustainable support to SME's and value chain management and forty percent said it enables the intervention of the government on capacity building of business operators in the country. The results show that the government managed to inform its high profile stakeholders about the SME policies and its intentions were clearly communicated to all the experts in the SME sector which include employees of the government departments, SME sector leaders, non-governmental organisations coordinators and various captains of the SME sector.

The process of informing the elite group of SME stakeholders was a noble idea for the government because this development was key to the successful implementation of the policy. In a normal government set up, this group of people are the custodians of the policy and their mandate would be to cascade the policy down to the lower structures, up to the implementers level. The experts would carry out various activities that include the policy awareness campaigns, training of local officers, dissemination of all the information, addressing any queries from the implementers and monitoring and evaluation of the progress being made by the implementers. This process was supported by Sobel et al. 2007) who state that public policies determine the entrepreneurial development of a country or region by introducing specific policies that need to be cascaded to all the institutional structures by the trained officers thereby creating conducive entrepreneurship environment. In this regard the government made a good start in the implementation process of the policy. This process leads the discussion to the second level which is the SME implementers and their awareness of the two policies.

\subsection{Awareness of the Two Polices Among the Implementers}

The Pearson's and Spearman's correlation measure that was used to measure the linear association between awareness of the policy and performance of SMEs (Table 3) indicated that there was no correlation between awareness of the policies and performance from 2015 to 2019. The casual analysis was also applied (table 6.8). A regression analysis was applied with: AWARE accounts for $1.3 \%\left(R^{2}=.013\right)$ of the variance in Performance $2019, F(10,488)=.664, p=.759$. The results imply that AWARE was not a significant predictor of Performance 2019. The results indicated that the SME implementers were not aware of the SME policies.

The results indicated that while the interviewees acknowledge the effort that was made by the government to inform them about the Indigenisation and Empowerment policy as well as the Industrial policy, the government did not do much to do the same to the SME implementers. Most of the implementers who responded to the questionnaire were not aware of the existence and the operational framework of the policies. The information from the respondents indicated that the percentage that did not hear about the policies (81.4\%) was very high, $65.9 \%$ did not have copies of the policy and $79.2 \%$ stated that the government did not distribute any information on the SME policies. The government failed to provide the policy information to its stakeholders. The action of the government in relation to the dissemination of the policy information was not aligned with the basic principles of policy formulation as stated by Aluko (2004), who asserts that policy is a guide to action, a means to an end, and not and end in itself and an instrument of management that has to be well communicated to its intended 
beneficiaries. A policy outlines the intended actions to all the stakeholders and it is carried out as a procedure and according to its contents hence its dissemination and sharing with all the stakeholders is mandatory (Majoni er al., 2016).

The government of Zimbabwe left everything to chance, ignored to follow the simple basic principles of policy formulation and implementation, hence the SME performance in Zimbabwe is very low and the general economic conditions continues to deteriorate. This was affirmed by the government through the report from the Government of Zimbabwe, (2009) which asserts that from 2006 all economic sectors posted low productivity, manufacturing went down by $7 \%$, agriculture was the most affected as it dropped by $73,3 \%$ and mining went down by $53,3 \%$ in 2008 . These sentiments were alluded by Kachembere, (2011)) who asserts that the industry across the whole country was operating at far below the normal production levels and reached below $5 \%$ in 2008.

\subsection{Effects of Government Policies on SME Performance}

The primary data indicated that the government did not do much to support its policies. The male respondent K03 from the mining sector emphasised that "As I have said it already. The government is not helping much. People are in need of money to buy the chemicals for blasting, compressors and so many more other mining equipment but that money is not coming at all". The participants who completed the questionnaire also indicated that the government policies did not help the to improve their performance. The results from the respondents indicate that the response 'Not at all' was selected significantly more than the other responses for all the items for example $80 \%$ of the respondents selected "Not at All" on the item which state "Government creates stimulating environment for high performance' received no response ( $0 \%$ ) on the option "To a great extent". This shows that the response "To a great extent" was least selected by the respondents. This is a clear indication that a significant number of the SME operators who responded to this section of the questionnaire stated that the government assistance did not help them to improve their performance.

The secondary data from the reviewed literature indicated that for the SMEs to have a high performance the government must be supportive and provide a conducive environment for production. According to Havav, (2017) the Institutional Theory is based on the assumption that an institutional environment influences the performance of organisations. The institutional theory states that an institution's environment is a strong force that can influence the development of structures in a firm more than any other forces. The term "institution" broadly refers to the formal rule set, agreements, and the behaviour of organisations in following the laws (Jepperson, 1991). The negative action of the government is a cause of concern as it failed to develop the SME sector into a vibrant economic hub that competes with other SMEs in the region.

The literature that has been reviewed provides excellent examples of governments that have supported the SME sector and high performing SMEs were developed. Government support policies on SMEs in Nigeria for example, consists of strategies and programmes employed by the government and their regulatory agencies to influence and determine decisions making process that foster economic growth by ensuring that the environment is adequately protected for business operations of the SMEs (Wakili et. al., 2016). In Ghana, the Economic Recovery Programme (ERP) instituted in 1983 has broadened the institutional support for SMEs, the National Board for Small Scale Industries (NBSSI) was established within the Ministry of Industry, Science and Technology to address the needs of small businesses (Peprah, Mensah \& Akosah, 2016). According to the Ministry of Industry and Trade (MolT) (2015) across Malawi, a broad range of support programmes targeting SMEs are being provided by different government departments and institutions as well as the private sector (Ndala \& Pelser, 2019). The high performance of SMEs follows the established supportive environment that is provided by the government, and these are the lessons that Zimbabwe can tap on and improve its economy through the SME sector

\section{Recommendations}

For the SMEs to contribute towards improved performance, job creation and poverty alleviation, it is recommended that the government need to align its policies with the needs of the country. This has to be done through a rigorous consultative process of all the stakeholders in the SME sector. The government has to go to the local communities, carry out the needs assessment, hold meetings in each region with SME implementers, employees and other stakeholders like the community

Page $12 / 20$ 
leaders, suppliers and incorporate their findings in the development of a new policy framework. This process will produce a Zimbabwean home grown SME policy which would be owned by both the government and the SME stakeholder.

It is recommended that Zimbabwean government should re-focus and craft a resource oriented policy that will be supported by a strategic framework that implements the new policy. The new policy and the strategic framework will be closely linked and the strategic framework will be supporting the policy. The strategic framework will be the mirror of the new policy developed. The two documents will work together and will be complementing each other.

It is recommended that a new strategic framework should contain the views of all the stakeholders. It will be an all-inclusive policy that will have been developed through the concerted efforts of all the stakeholders. After the government has put together the home grown SME policy, it will develop the strategic road map, establish the support structures and develop the implementing guidelines which provide the model that will be adopted by the strategic framework rollout programme. The strategic framework will contain the logical processes that have to be followed by the stakeholders and each participant of the programme will be well informed about all the contents and the procedure of implementing the strategic plan.

\section{Conclusions}

The data collected has indicated that the interviewees have high knowledge levels of the Zimbabwe empowerment policies. The questionnaire respondents have shown low levels of policy awareness. Information about the SME programmes was disseminated through public media and most of the implementers were not able to access the information. The information dissemination method that was used by the Zimbabwean government was ineffective and the policy implementation process flopped.

The researcher has drawn two conclusions on how the government policies influence the performance of SMEs in Zimbabwe. Firstly, the SME implementers have very little knowledge about the indigenisation and empowerment policy and the industrialisation policy that were designed to promote SMEs in Zimbabwe. The government does not have any mechanism in place to distribute information in the form of pamphlets, brochures, fliers or billboards about the policies. The policies were not made available to the end users and no print or electronic materials were distributed to the SME implementers. The government did not make any consultations with the SME implementers it only operated from the office and used a desk top approach in the implementation of its policies. The implementers did not benefit much from the two policies and their operations are not guided by the policies. In a nutshell the government of Zimbabwe failed to put into practice what it developed hence the poor performance of SMEs.

Secondly the government policies have very little influence on the performance of SMEs in Zimbabwe. The government does not have any policy commitment towards providing the implementers with the technical assistance which they so much require and has no programmes to promote research and development. The government has no platforms that promote information sharing like forming the sectoral groups and developing networking committees for peer training and peer education. It is not involved any support of SME activities like the marketing of the products, access to fuel and electricity and provide duty exemptions on the inputs. Therefore, the government has to go back to the drawing board and re-strategise in order to turn around the economy of Zimbabwe through SMEs.

\section{Abbreviations}

B.B.E. E

Broad Black Economic Empowerment

BIDPA

Botswana Institute for Development Policy Analysis

CEDA

Citizen Entrepreneurial Development Agency

EET)

Page 13/20 
Entrepreneurship Education and Training

FTLRP

Fast Track Land Reform Programme

FAP

Financial Assistance Policy

GDP

Gross Domestic Product

HEls

Higher Education Institutions

MARDEF

Malawi Rural Development and Enterprise Fund

NCHE

National Council for Higher Education

SME

Small and Medium Enterprise

SMME

Small Medium Micro Enterprise

TEVETA

Technical Education, Vocational and Entrepreneurial Training Authority

\section{Declarations}

\section{Availability of data and material}

The data that support the findings of this study are available from my archives were it is stored after conducting the interviews and administering the questionnaires

\section{Competing interest}

"The authors declare that they have no competing interests" in this section.

\section{Funding}

The authors funded the research process

\section{Authors' contributions}

All authors read and approved the final manuscript."

\section{Acknowledgements}

"Not applicable"

\section{Authors' information}

N/A

\section{References}

Abor, J. \& Biekpe, N. (2006). "Small Business Financing Initiatives in Ghana”, Problems and

Perspectives in Management, 4(3), pp. 69-77. 
Addae, D \& Quan-Baffour, K. P. (2015). The place of mixed methods research in the field of adult education: design options, prospects and challenges. International Journal of Education and Research Vol. 3 No. 7 July 2015. ISSN: 2411-5681 www.ijern.com.

AFDB/OECD. (2005). Botswana, African Economic Outlook 2004/2005, pp. 105-117.

Khanie, G. (2018). Financing SMEs in Botswana: Factors Influencing Access to Credit Botswana Institute for Development Policy Analysis, 2018 ISBN: 9991265589.

AFRICA REPORT. (2018). 42-43.

http://www.mlimienterprises.com/publications/china_africa_training.pdf.

Awiagah, R., Kang, J., \& Lim, J. (2015). Factors affecting e-commerce adoption among SMEs in Ghana. Information Development 1-22 sagepub.co.uk/journalsPermissions.nav

DOI: 10.1177/0266666915571427 idv.sagepub.com Ajou School of Business, South Korea.

Block, E. (2013). The Zimbabwean situation latest headline News-Zimbabwe. Available online http://www.zimbabwesituation.com/aug20_2013.html Accessed March 2014.

Delaney, P. B., Harrington, K. \& Toker, E. (2019). Undergraduate Student-Run Business Development Services: A New Educational Opportunity and Growth Alternative for Small and Medium Enterprises. Entrepreneurship Education and Pedagogy 2(2):171-187.

Department of Trade and Industry, (2007). A strategy for Broad-Based Black Economic Empowerment (online). http://www.dti.gov.za/ economic_empowerment/ bee_codes. jsp (Accessed 30 September 2017).

Fjose, S., Grunfeld, L. A. \& Green, C. (2010). SMEs and growth in Sub-Sahara Africa: Identifying SME Role and obstacles to SME growth. MENON-Publication, 14, 1-28.

GEM. (2005). Global entrepreneurship monitor. The South African Report. UCT Centre for Innovation and Entrepreneurship.

Government of Kenya, (2007). Wealth and Employment Creation for Poverty Reduction: A Ministry of Trade Initiative. Nairobi: Government Printer.

Hansen, M., Buur, L., Mette, K., \& Therkildsen, O. (2015). The Economics and Politics of Local Content in African Extractives: Lessons from Tanzania, Uganda and Mozambique, Forum for Development Studies, DOI: 10.1080/08039410.2015.1089319.

Ibrahim, M. I. \& Mustapha, B. (2019). Determinants of Small and Medium Enterprises Performance in Nigeria: The Role of Government Support Policy. International Journal of Business and Economics Research. Vol. 8, No. 2, 2019, pp. 41-49. doi: 10.11648/j.jjber.20190802.1.

Ifekwem, N.E. (2019). Government Policy and the Growth of Small and Medium Scale Enterprise in Lagos State. Pacific Journal of Science and Technology. 20(1):201-21.

Juggernath, S., Rampersad, R., \& Reddy, K. (2013). Corporate responsibility for socioeconomic transformation: A focus on broad-based black economic empowerment and its implementation in South Africa. African Journal of Business Management, 5(20), 8224-8234.

Kamunge, M. S., Njeru, A. \& Tirimba, O. I. (2014). Factors affecting the performance of small and macro enterprises in Limuru town market of Kiambu County. International Journal of Scientific and Research Publications, 4(12),1-20.

Kauffmann, C. (2006). Financing SMEs in Africa. Paris: OECD Development Centre, Policy Insight nr 7

Page $15 / 20$ 
Kayanula, D. \& Quartey, P. (2000). The Policy Environment for Promoting Small and Medium- Sized Enterprises in Ghana and Malawi, Finance and Development Research Programme, Working Paper Series Paper No. 15, IDPM, University of Manchester.

Kenya National Bureau of Statistics, (2016). https://www.knbs.or.ke.

KIPPRA, (2017). Kenya Economic Report 2017: Sustaining Kenya's Economic Development by

Deepening and Expanding Economic Integration in the Region, KIPPRA.

Krasniqi, B. (2007). Barriers to entrepreneurship and SME growth in transition: the case of Kosova. Journal of Developmental Entrepreneurship, 12(1), $71-94$.

Lee, N. (2008). Doing Business Research. A guide to Theory and Practice. SAGE Publishing, Inc. Los Angeles.

Local Enterprise Authority. (2009). 2007 Needs Assessment Study for the SMME Sector and Business Development Service Providers Report. Gaborone, Botswana.

Magaisa, G. \& Matipira, L. (2019). Small and medium enterprises development in Zimbabwe. International Journal of Economy, Management and Social Sciences Vol (6), No (2), June, 2017

Majoni, T., Mutunhu, J., \& Chaderopa, B. (2016). SME’s policies and challenges: A

comparative analysis of Zimbabwe and South Korea. International Journal of

Scientific and Research Publications, 6, 377-384. Retrieved from http://www.ijsrp.org.

Mujeyi, K., Mutambara, J., Siziba, S., Sadomba, W. Z., \& Manyati, T. K. (2015). Entrepreneurial innovations for agricultural mechanisation in Zimbabwe: Evidence from an informal metal industry survey. African Journal of Science, Technology, Innovation and Development, 7(4), 276-285.

Muriithi, S. (2017). African small and medium enterprises (SMEs) contributions, challenges and solutions.

Mwarari, M. M. \& P. K. Ngugi (2013). Factors influencing listing of Kenyan SMEs in the securities market for capital raising opportunities. European Journal of Management Sciences and Economics, 1(2), 99-115.

Ndala, N.N. \& Moto, F. (2019). Assessing the Access to Finance by Small and Medium-Sized Enterprises from Financial Institutions in Blantyre City-Malawi International Journal of Business and Management; Vol. 14, No. 5; 2019 ISSN $1833-3850$ E-ISSN 1833-8119.

Ndala, N. \& Pelser, T. (2019). Examining the Effectiveness of Entrepreneurship Policy Implementation in Malawi Journal of Contemporary Management Volume 16 Issue 2,

DOI nr: https://doi.org/10.35683/jcm19036.34.

Ombongi, P.N. \& Long, W. (2018). "Factors Affecting Financial Performance of Small and Medium Enterprises (Smes): A Case of Manufacturing SMEs in Kenya." International Journal of Research in Business Studies and Management, vol 5, no. 1, 2018, pp. 37-45

Omonobi, K., \& Bivbere, G. (2016). Customs Re-imposed Ban on Rice Importation. Retrieved May 6, 2016, from http://www.vanguardngr.com/2016/03/customs-re-imposesban-rice-importation/.

Osinbajo, Y. (2015). Buhari offer Concessionary Funding to SMEs. Retrieved April 24, 2015, from http://thenewsnigeria.com.ng/2015/09/buhari-to-offerconcessionary-funding-to-smes/. 
Osoro, K. \& Muturi, W. (2013). The Role of Micro Financial Institutions On the Growth of Smes in Kenya: A Case Study of Micro Financial Institutions in Kisi Town IOSR Journal of Humanities and Social Science (IOSR-JHSS) Volume 16, Issue 1 (Sep. - Oct. 2013), PP 83-93 e-ISSN: 2279-0837, p-ISSN: 2279-0845. www.losrjournals.Org.

Parker, J.C. (2006). Micro and small-scale enterprises in Zambia: results of the 1996 nationwide survey. London: Graham Bannock and Partners Ltd.

Rust, K. (2006). Analysis of South Africa's housing sector performance., Johannesburg, South Africa: FinMark Trust.

Santarelli, E. \& Vivarelli, M. (2007). Entrepreneurship and the process of firms' entry, survival and growth. Industrial and Corporate Change, 16 (3), 455-488.

Sawers, J. L., Pretorius, M. W., \& Oerlemans, L. A. G. (2008). Safeguarding SMEs dynamic capabilities in technology innovative SME-large company partnerships in South Africa. Technovation, 28(4):

Sobel, R. S., Clark, J.R. \& Lee, D. R. (2007). Freedom, Barriers to Entry, Entrepreneurship, and Economic Progress. Review of Austrian Economics, 20: 221-36.

Udechukwu, F. N. (2003). Survey of small and medium scale industries and their potentials in Nigeria. In CBN Seminar on SMIEIS (pp. 2-11).

Wakili, I. (2016). Nigeria Can Survive without Oil. Retrieved June 28, 2016, from

http://www.dailytrust.com.ng/news/general/nigeria-cansurvive-without-oil-osinbajo/131850.html.

Wang, C., Walker, E., \& Redmond, J., (2011). Explaining the lack of Strategic planning in SMEs: The Importance of Owner Motivation. International journal of Organisational behaviour, ECU Publication Press.

Willemse, J. (2010). The forum SA: SME failure statistics. Retrieved on September 1st, 2016 from: http://www.theforumsa.co.za/forums/showthread.php?t=7808.

World Bank. (2016). World Bank Data. Available online at: http://data.worldbank.org/ (accessed on 10 March 2016).

Zvarivadza, T. (2018). Artisanal and Small-Scale Mining as a challenge and possible contributor to Sustainable Development. Resources Policy, 56, 49-58.

doi: 10.1016/j.resourpol.2018.01.009.

\section{Figures}




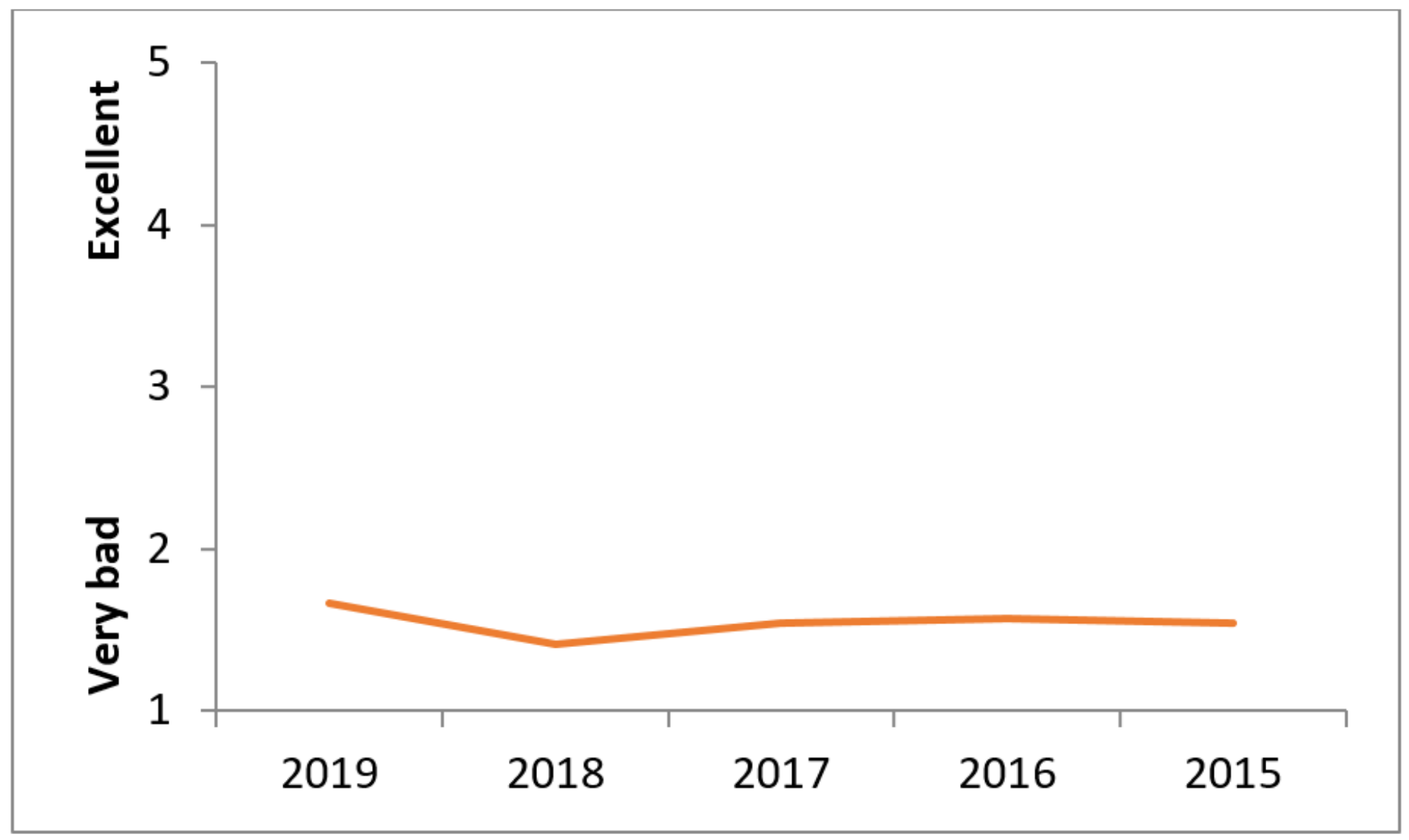

Figure 1

Consolidated results 


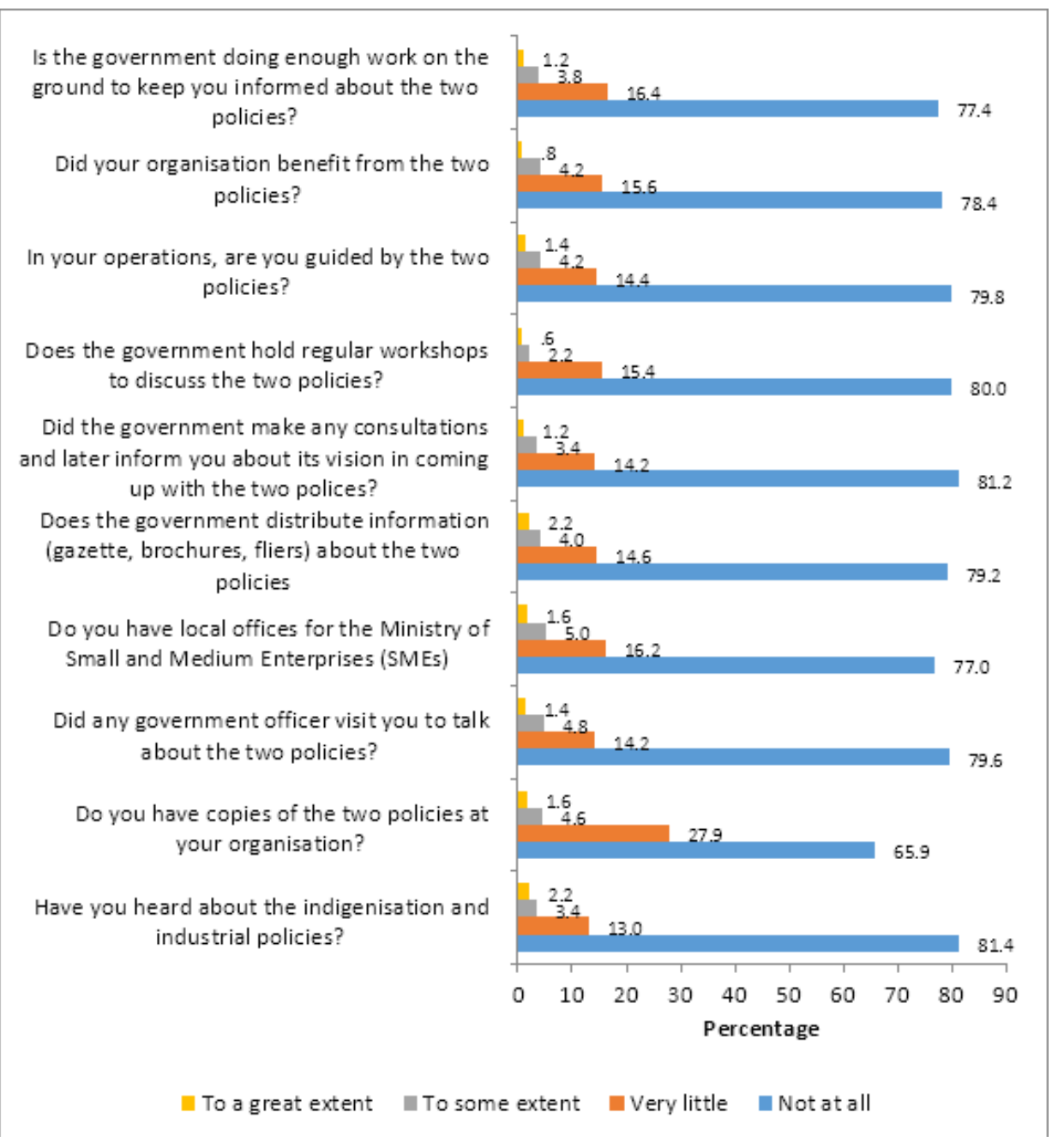

Figure 2

Awareness of the two polices among the implementers Graphical representation of the results indicating awareness of the Indigenisation and Empowerment Policy and the Industrial Policy. 


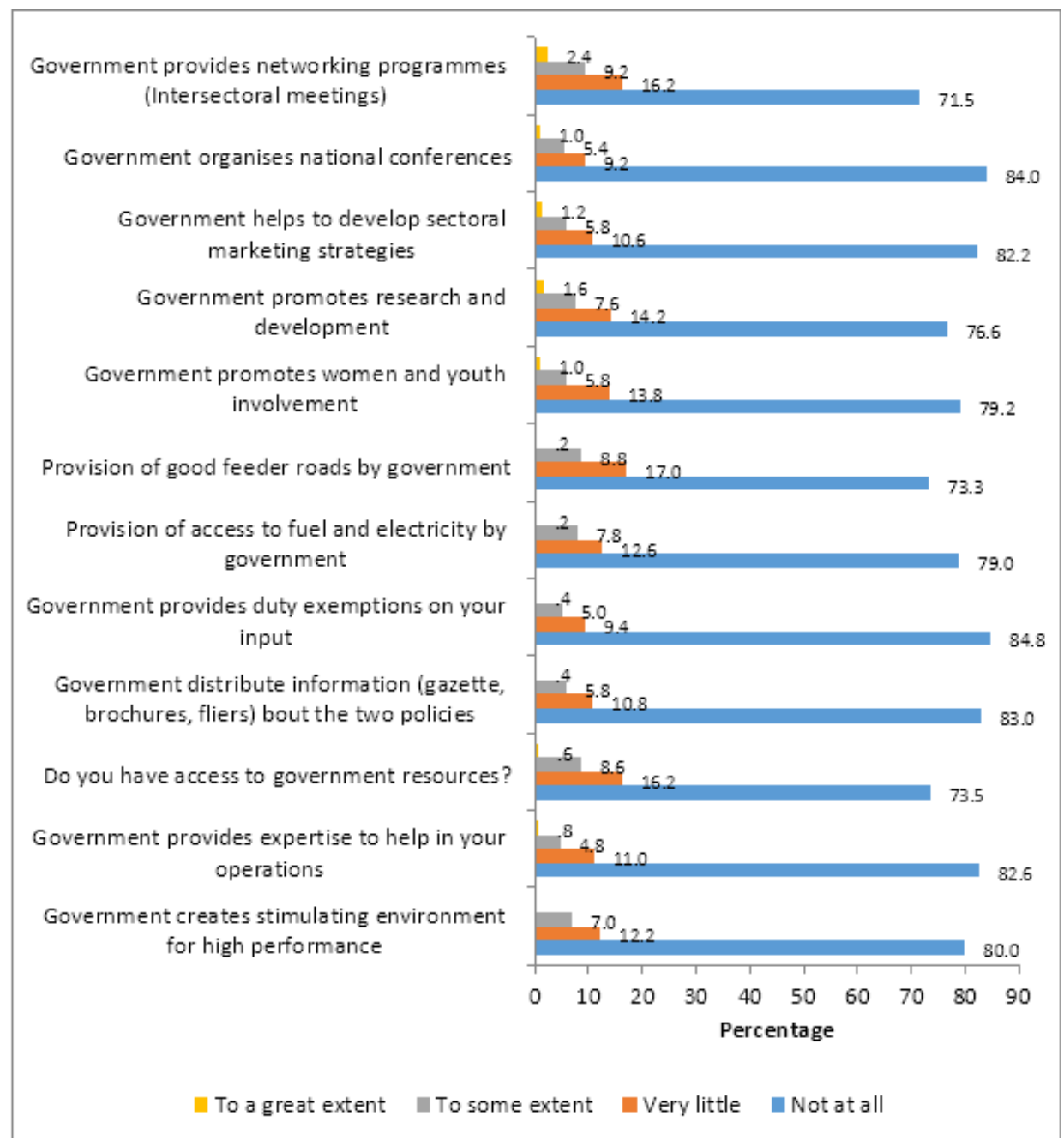

\section{Figure 3}

Effects of government policies on SME performance (Questionnaire Respondents) 